IZA DP No. 9791

Does Bilingualism among the Native Born Pay?

Barry R. Chiswick

Paul W. Miller

March 2016 


\title{
Does Bilingualism among the Native Born Pay?
}

\author{
Barry R. Chiswick \\ George Washington University \\ and IZA \\ Paul W. Miller \\ Curtin University \\ and IZA
}

\section{Discussion Paper No. 9791 \\ March 2016}

\author{
IZA \\ P.O. Box 7240 \\ 53072 Bonn \\ Germany \\ Phone: +49-228-3894-0 \\ Fax: +49-228-3894-180 \\ E-mail: iza@iza.org
}

Any opinions expressed here are those of the author(s) and not those of IZA. Research published in this series may include views on policy, but the institute itself takes no institutional policy positions. The IZA research network is committed to the IZA Guiding Principles of Research Integrity.

The Institute for the Study of Labor (IZA) in Bonn is a local and virtual international research center and a place of communication between science, politics and business. IZA is an independent nonprofit organization supported by Deutsche Post Foundation. The center is associated with the University of Bonn and offers a stimulating research environment through its international network, workshops and conferences, data service, project support, research visits and doctoral program. IZA engages in (i) original and internationally competitive research in all fields of labor economics, (ii) development of policy concepts, and (iii) dissemination of research results and concepts to the interested public.

IZA Discussion Papers often represent preliminary work and are circulated to encourage discussion. Citation of such a paper should account for its provisional character. A revised version may be available directly from the author. 


\section{ABSTRACT \\ Does Bilingualism among the Native Born Pay?*}

This paper uses the pooled data from the 2005-2009 American Community Survey to analyze the economic benefits of bilingualism to adult men born in the United States. Bilingualism among the native born is defined as speaking a language at home other than or in addition to English. Native born bilingualism is rare; only 6.5 percent report a non-English language, and of those 71 percent report Spanish. Most of the native born bilinguals report speaking English "very well" (85 percent), with most of the others speaking it "well" (10 percent). Other variables the same, bilinguals earn 4.7 percent less than monolingual English speakers, but the earnings differential varies sharply by the language spoken. Those who speak Native American languages, Pennsylvania Dutch and Yiddish have very low earnings, likely because they live in isolated geographic or cultural enclaves. Those who speak certain Western European and East Asian languages and Hebrew earn significantly more than monolingual English speakers. Spanish speakers earn 20 percent less than the monolingual English speakers overall, but other variables the same, have statistically significant seven percent lower earnings.

JEL Classification: J24, J31, F22

Keywords: $\quad$ bilingualism, earnings, native born, linguistic enclaves

Corresponding author:

Barry R. Chiswick

Department of Economics

George Washington University

2115 G Street, NW

Monroe Hall 340

Washington, DC 20052

USA

E-mail: brchis@uic.edu

\footnotetext{
* We appreciate the research assistance of Marina Gindelsky and Derby Voon. Miller acknowledges financial assistance from the Australian Research Council. Miller passed away after a long illness during the preparation of this paper.
} 


\section{Does Bilingualism Among the Native Born Pay?}

\section{INTRODUCTION}

Over the past few decades a literature has developed on the determinants and labor market consequences of the destination language proficiency of immigrants in developed economies. Very little is known, however, of the labor market consequences, if any, of the language skills of the native born in a country who are bilingual, that is, individuals who are proficient in the language of their country of birth, where they live, and have some degree of proficiency in another language.

This study focuses on these "native-born bilinguals". Although the topic is of broader interest, the application in this study is to the adult male population born in and living in the United States. In particular, the interest is on the extent to which limited English proficiency and proficiency in another language affects their earnings. ${ }^{1}$

Section II develops a methodology to explore these issues and discusses the data used in the empirical estimates, namely the American Community Survey for 2005-2009. It also reviews the surprisingly sparse literature on the labor market effects of bilingualism among the native born in a developed country.

Section III starts with descriptive statistics on the native-born Americans who speak a language other than English at home and have limited English-language proficiency. It then presents the results of the multivariate analysis (ordinary least

\footnotetext{
${ }^{1}$ The main studies on this topic are Chiswick and Miller (1998) and Fry and Lowell (2003, 2005). For studies of the determinants and labor market consequences of destination language proficiency among immigrants, see Chiswick and Miller (2007a) and Chiswick and Miller (2008), and the references therein. For other studies of bilingualism see Coomer (2011), Henley and Jones (2005), Linton (2004), Toomet (2011).
} 
squares and quantile regressions) of the effects on earnings of speaking another language and English-language proficiency among adult male native-born Americans. In Section V is a summary and conclusion.

\section{THE MODEL AND THE DATA}

\section{A. $\quad \underline{\text { The Model }}$}

Language skill is a form of human capital. It satisfies the three requirements: It is embodied in the person; it is created at a cost (in time or money) to the individual or to others; and it is productive in the labor market, consumption or other activities (Becker 1964, Chiswick and Miller, 2007a). Native-born bilinguals may learn a language other than English at home from their parents, other relatives or caregivers, because it is the language of immigrant relatives and caregivers, or the language of a racial, ethnic or religious minority group. Others may have learned the language through marriage to a foreign-language speaker, or through an educational program at school for work or other reasons.

Those deficient in language skills relevant for the consumer market will find it more difficult (costly) to search for the lowest price, or the highest quality for a given price, of the goods and services they may wish to purchase. Searching for information regarding prices, quality and efficacy of a good or service requires a degree of speaking proficiency and/or literacy.

Language skills are important in the labor market. ${ }^{2}$ The language skills may be required for the job because of oral communication with others (e.g., customers,

\footnotetext{
${ }^{2}$ There have been several studies in recent years on the effects of destination language proficiency on the earnings of immigrants in the United States (see Chiswick and Miller, 2008) and several other immigrant receiving countries, including Australia, Canada, Israel, Germany, New Zealand and the Netherlands. (See, for example, Chiswick and Miller (1995).) These studies consistently show that, among immigrants, the lower the degree of proficiency in the destination language, whether measured by
} 
suppliers, supervisors, subordinates or peers) or because literacy (reading, writing or both) may be needed for the person to do the job efficiently or to do it safely.

If language skills are a form of human capital, individuals will invest in these skills and will use them in consumption and production activities so as to maximize their own economic well-being, subject to various constraints, including innate ability, home environment, school quality, etc. These constraints include one’s own time, the value of this time, the prices of purchased inputs or the opportunity cost of time needed for the production of human capital.

The primary language in the US labor market is English, and it would be reasonable to hypothesize that, at least up to some point, greater proficiency in English is associated with greater productivity in the labor market, and hence will result in higher earnings. Someone with greater proficiency could, presumably, do a job that could be done by someone with lesser proficiency, but in addition would have job opportunities that would not be available to someone with a lower degree of proficiency.

A person who is fully proficient in English but who also has some proficiency in another language may have an additional economic advantage. Knowledge of a second language may expand job opportunities. This could arise if that language was valuable in international trade or finance, or in economic interactions with suppliers, co-workers, customers, or others who use that language, perhaps because they are immigrants, or are otherwise linguistic minorities. Other things being the same, knowing another language should not detract from earnings as the person could, in principle, hide this information from the labor market.

speaking skills or by literacy, the lower are the earnings of immigrants, even when other measured variables are held constant. 
There are, however, circumstances in which a person who speaks a language other than English, as well as being able to speak English, incurs an economic disadvantage. This could arise, for example, if the speaking or studying of the other language detracts from the individual's full proficiency in English or detracts from acquiring other forms of human capital. That is, the person may be bilingual, but not fully proficient in English, and the returns, if any, from knowing the other language are more than offset by the negative effects on earnings from deficiencies in English. It may also arise if the bilingualism is associated with an accent or intonation, or in some other way signals ethnicity or an immigrant ancestry, and if this serves as a basis for discrimination in the labor market. The discrimination may be pure prejudice against those with a particular accent, speech pattern or ethnicity, or it may be based on the false notion that this implies less education or less ability. ${ }^{3}$

In addition, speaking a language other than English may, for some, reflect partial or total isolation from the mainstream American economy. This may arise from either growing up in, or currently living and working in, an immigrant/ethnic/religious/Indigenous group enclave. The enclave may be based on geographic or cultural isolation. Having been raised in such an environment may result in less human capital acquired in the home as a child, or in school, relevant for the mainstream American economy, as distinct from the ethnic community or ethnic labor market. Those with limited English-language proficiency, but with knowledge of another language, may optimize their labor market success by working in a partial or full minority language enclave in which the non-English language serves as a partial or primary medium of communication (see Chiswick and Miller, 2005). Some

\footnotetext{
${ }^{3}$ Language may serve as a basis for Becker-type 'tastes' for discrimination, or for Phelps' statistical discrimination (see Becker, 1957, and Phelps, 1972). These same points may apply to regional or social class speech patterns.
} 
may be willing to sacrifice labor market training and earnings for participation in religious or ethnic practices that require learning a language of that religion or ethnicity.

It is, therefore, an empirical question as to the extent to which limited Englishlanguage proficiency penalizes native born individuals in the labor market and the extent to which native born bilingualism, in the sense of being proficient in English but with knowledge of another language, enhances or retards labor market opportunities. $^{4}$

\section{B. The Data}

The analyses in this paper are based on the pooled samples of the 2005-2009 American Community Survey (ACS). This is an ongoing annual survey of around one percent of the US population. Participation in the survey is compulsory for the selected sampling units (housing units and group quarters), and consequently the nonresponse rate is very low, at around two percent for housing units. The survey for each year comprises 12 monthly independent samples. It covers all states and the District of Columbia, and the data are released to the research community in the form of a Public Use Microdata Sample (PUMS). This contains details on a wide range of demographic and labor market characteristics, including birthplace, languages spoken at home, proficiency in English (among those who speak a language other than English at home), earnings and weeks worked. Data from the surveys for 2005 through to 2009 are pooled, with the earnings data adjusted to a common year (2005).

\footnotetext{
${ }^{4}$ While the focus in this paper is on the economic (earnings) consequences of bilingualism, it is noted that bilingualism may be associated with, and motivated by, a wider set of outcomes. As Christofides and Swidinsky (2010: 138) note, the factors behind the choice to learn a second language '...include, among others, cultural, intellectual, linguistic, scientific, political, personal, and economic reasons.'
} 
It is noted that, in common with the earlier census data sets (see the analyses by Chiswick and Miller (1998) and Shin and Alba (2009)), the American Community Survey does not contain information on the level of proficiency in any foreign language, on the level of proficiency in English of those who speak only English at home, on language skills other than speaking skills or languages used outside the household. These acknowledged limitations are off-set by the very large sample size, which facilitates analyses undertaken for specific language groups.

In the analyses below, we follow Shin and Alba (2009) and Chiswick and Miller (1998) by defining a bilingual as someone who speaks a language other than English at home and speaks English very well. We retain all workers with limited English skills in the sample initially, though we follow Christofides and Swidnsky (2010) and remove in tests of robustness the very small number of observations among those reported to be born in the US but who report they cannot speak English at all.

\section{STATISTICAL ANALYSES}

\section{A. Descriptive Analyses}

Table 1 lists the distribution and average annual earnings of adult (age 25 to 64 years) native-born males by English language proficiency. The sample is restricted here to workers who reported non-zero earnings and positive weeks worked in the year prior to the survey. Those who speak only English at home record the highest average earnings, of $\$ 56,515$, and this is by far the majority group in the United States, comprising 93.5 per cent of the sample. Among the native-born males who speak a language at home other than English most speak English very well (5.5 per cent of the sample and 85 percent of those who speak another language at home). Only a 
relatively small proportion of the sample report speaking English well (0.66 per cent), not well (0.30 per cent) or do not speak English at all (0.04 per cent).

Table 1

Average Earnings of Native-Born Males Age 25 to 64 years by English Language Skills

\begin{tabular}{|lccc|}
\hline & \% & \% & $\begin{array}{c}\text { Average Annual } \\
\text { Earnings (\$) }\end{array}$ \\
\hline Speaks English Only & 93.47 & & - \\
\hline Speaks Language Other than & & & 56,515 \\
English and: & & & \\
$\quad$ Speaks English Very Well & 5.53 & 84.7 & 49,588 \\
$\quad$ Speaks English Well & 0.66 & 10.1 & 41,517 \\
$\quad$ Speaks English Not Well & 0.30 & 4.6 & 44,175 \\
$\quad$ Speaks English Not at All & 0.04 & 0.6 & 25,518 \\
\hline
\end{tabular}

Source: American Community Survey 2005-2009.

Note: Earnings converted to 2005 dollars using the CPI.

Native-born men who speak a language other than English at home earn, on average, less than those who speak only English. The group that speaks a language other than English at home but possesses very high English proficiency skills on average earn $\$ 49,588$ (which is 12.3 per cent less than the monolingual Englishspeaking group), whereas the three groups with limited English-speaking skills (speaks English well, not well or not at all) have average earnings 26.5 per cent, 21.8 per cent and 54.8 per cent, respectively, less than the monolingual English speakers. The first of these other language groups (who speak a language other than English at home and speak English very well) is the group usually classified as bilingual (see Section II). Hence, the aggregate level evidence from the American Community Survey 2005-2009 is consistent with that reported on the basis of analyses of earlier census data.

Table 2 lists the distribution and average annual earnings of bilingual speakers across the 22 most frequently reported language groups by English proficiency 
levels. ${ }^{5}$ The table is ordered according to the percentage distribution of all second language speakers (the first column of figures), and contains information for all second-language speakers (the first two columns of data), for bilinguals (the middle two columns), and for those with English-speaking limitations (the final two columns).

This table shows the dominance of Spanish as a second language (accounting for 71 per cent of second language speakers), and that the three next most important languages, German, French, and Italian, combined constitute less than 12 percent of the second language speakers. The figures in Table 2 reveal considerable variation in the earnings of the various second language groups identified. Note the relatively low mean earnings of those whose second language is Spanish: nearly $\$ 44,000$. Given the numerical importance of this group the mean earnings of the other language groups combined $(\$ 59,295)$ exceeds the mean earnings of the English monolingual speakers $(\$ 56,515)$.

Table 2

Distribution of Second Language Speakers and Average Earnings across Major Language Groups, by Proficiency in English, Adult Native-Born Men

\begin{tabular}{|lcccccc|}
\hline Language & \multicolumn{2}{c}{$\begin{array}{c}\text { All Second } \\
\text { Language } \\
\text { Speakers }\end{array}$} & \multicolumn{2}{c}{$\begin{array}{c}\text { Speaks } \\
\text { English Very Well }\end{array}$} & \multicolumn{2}{c|}{$\begin{array}{c}\text { Speaks } \\
\text { English Well, Not } \\
\text { Well or Not At All }\end{array}$} \\
\cline { 2 - 7 } & $\mathbf{\%}$ & $\mathbf{\$}$ & $\mathbf{\%}$ & $\mathbf{\$}$ & $\mathbf{\%}$ & $\mathbf{\$}$ \\
\hline Spanish & 70.75 & 43,876 & 70.30 & 45,037 & 73.28 & 37,687 \\
Non-Spanish & 29.25 & 56,570 & 29.70 & 60,357 & 26.72 & 52,747 \\
German & 4.75 & 61,813 & 4.75 & 62,799 & 4.76 & 56,349 \\
French & 4.25 & 64,151 & 4.30 & 64,942 & 3.98 & 59,401 \\
Italian & 2.73 & 68,805 & 2.86 & 68,741 & 2.05 & 69,299 \\
Greek & 1.18 & 70,644 & 1.27 & 70,904 & 0.67 & 67,919 \\
Portuguese & 1.07 & 58,542 & 1.16 & 59,204 & 0.61 & 51,509 \\
Japanese & 1.06 & 62,978 & 1.09 & 63,218 & 0.89 & 61,352 \\
Chinese & 1.00 & 63,864 & 1.00 & 65,027 & 0.97 & 57,180 \\
Navaho & 0.94 & 30,863 & 0.92 & 31,304 & 1.03 & 28,661 \\
Polish & 0.71 & 57,418 & 0.68 & 57,958 & 0.86 & 55,017 \\
Arabic & 0.69 & 54,471 & 0.72 & 56,733 & 0.57 & 38,570 \\
Tagalog & 0.65 & 48,152 & 0.67 & 49,070 & 0.50 & 41,241 \\
Korean & 0.63 & 59,969 & 0.61 & 60,945 & 0.73 & 55,426
\end{tabular}

${ }^{5}$ The cut-off for the inclusion of a language group in the table was (arbitrarily) specified as having 500 speakers (unweighted data). 


\begin{tabular}{|lcccccc|} 
Hebrew & 0.62 & 88,396 & 0.68 & 90,312 & 0.32 & 65,959 \\
Penn. Dutch & 0.61 & 48,923 & 0.53 & 49,772 & 1.05 & 46,536 \\
Russian & 0.59 & 63,458 & 0.59 & 63,628 & 0.59 & 62,519 \\
Yiddish & 0.48 & 46,768 & 0.41 & 53,447 & 0.87 & 29,356 \\
Vietnamese & 0.45 & 40,345 & 0.42 & 42,125 & 0.61 & 33,509 \\
Other Amer. Indian & 0.43 & 28,979 & 0.44 & 28,775 & 0.36 & 30,371 \\
Cantonese & 0.35 & 67,082 & 0.36 & 66,273 & 0.29 & 72,677 \\
Dutch & 0.35 & 64,876 & 0.34 & 67,777 & 0.42 & 51,959 \\
Eskimo & 0.17 & 26,994 & 0.14 & 27,878 & 0.33 & 24,942 \\
All Others & 5.54 & 54,338 & 5.77 & 55,300 & 4.28 & 47,129 \\
\hline Total & $\mathbf{1 0 0}$ & $\mathbf{4 8 , 3 8 6}$ & $\mathbf{1 0 0}$ & $\mathbf{4 9 , 5 8 8}$ & $\mathbf{1 0 0}$ & $\mathbf{4 1 , 7 1 1}$ \\
\hline
\end{tabular}

Source: American Community Survey 2005-2009.

Note: Data on earnings are in 2005 dollars. The mean earnings of monolingual English speakers is $\$ 56,515$.

Nevertheless, this summary statement about the remaining languages is too sweeping, as there is a great deal of variation across these groups. Hence, it is apparent that most of the bilinguals with a European language as their second language, and particularly those with German, French, Italian, Greek or Dutch as a second language, record an average earnings greater than the $\$ 56,515$ of the English monolingual speakers. Greek bilingual speakers have the highest average earnings, at around \$71,000, while the bilingual speakers with Italian as their second language have an average earnings only slightly less, at around $\$ 69,000$. A number of other second language groups originating from Europe are also characterized by relatively high earnings, including the Portuguese, Polish and Russian languages. Another bilingual group with average earnings higher than the English monolingual speakers is those who speak Hebrew, who have average earnings of around \$88,000.

The data in Table 2 also show that the majority of the bilingual speakers with an Asian second language (Japanese, Chinese, Cantonese and Korean) have average earnings above the level of their monolingual English-speaking counterparts. EnglishCantonese bilingual speakers are found to have the highest earnings among this group, with average earnings around $\$ 67,000$. In contrast, the other two Asian language 
groups identified in the table, Vietnamese and Tagalog, have relatively low average earnings.

There are five other second languages associated with relatively low earnings. The three Indigenous languages separately identified (Navaho, Other North-American Indian languages and Eskimo) fall into this category, as do bilinguals whose other language is either Pennsylvania Dutch or Yiddish. While the mean earnings of those who speak Pennsylvania Dutch (the Amish) or Yiddish (often linked today to communities of ultra-orthodox Ashkenazi Jews) are only slightly below the mean earnings for the English monolingual group, the mean earnings for the Indigenous language groups are as much as 52 per cent lower than the earnings of the English monolinguals. ${ }^{6}$

Hence, it is apparent from these data that native-born bilinguals are a heterogeneous group, with some language groups having quite high average earnings and others having relatively low average earnings. These variations in mean earnings could reflect either the characteristics of the workers, or the net labor market demand for the particular language skill possessed (see Ginsburgh and Prieto-Rodriguez, 2011). The multivariate analyses presented below will assist in determining which of these explanations is more likely to account for the patterns in Tables 1 and 2.

\footnotetext{
${ }^{6}$ The ACS data do not permit the identification of the location of indigenous peoples who live in isolated rural areas or on Native American reservations. By their own choice the Amish leave school at very young ages (mean schooling of adult men who speak Pennsylvania Dutch is 8.9 years). By the year 2005, the adult male Yiddish speakers in the US are primarily "ultra-orthodox" Ashkenazic Jews who sacrifice learning secular skills in their own schools for religious studies and after leaving school devote a considerable amount of time to religious studies and practice, at the expense of obtaining secular schooling and on-the-job training that would increase their labor market earnings.
} 


\section{(b) $\underline{\text { OLS Analyses }}$}

Table 3 lists estimates from two models of earnings determination. In the first the earnings equation is given as:

$\ln \mathrm{Y}=\mathrm{f}$ (educational attainment, experience, experience ${ }^{2}$, married, weeks worked, black, year, south, bilingual, limited English skills)

where $\ln \mathrm{Y}$ is the natural logarithm of annual labor market earnings, educational attainment is the years of full-time equivalent schooling for the worker, experience is the years of potential labor market experience, measured as age minus years of education minus six, and the remaining variables are largely self-explanatory, though definitions are provided in Appendix A. Of note is that this first model includes two language proficiency variables. The first is a dichotomous variable for workers who speak a language other than English at home and speak English very well (that is, fully bilingual). The second variable is for workers who speak a language other than English at home and have less proficiency in English. ${ }^{7}$

The second specification is designed to explore in more detail the earnings position of the group of bilinguals. Hence, the single variable for being bilingual is replaced by four mutually exclusive and exhaustive variables: ${ }^{8}$ English-Spanish bilingual; English-Indigenous language bilingual; English-other major second language bilingual; and English-residual second language bilingual. Hence the second model is given as:

$\ln \mathrm{Y}=\mathrm{f}$ (educational attainment, experience, experience ${ }^{2}$, married, weeks worked, black, year, south, English-Spanish bilingual, English-Indigenous language bilingual, English-other major second language bilingual, English-residual second language bilingual, limited English skills)

\footnotetext{
${ }^{7}$ The regressions in Tables 3 and 4 include all second language speakers. Deleting those who report speaking English less than "very well" has no material effect on the results.

${ }^{8}$ The major second languages are defined on the basis of numerical representation, and are the languages separately identified in Table 2.
} 
The estimates of the first model outlined above are presented in column (i) of Table 3. The findings for the educational attainment, potential labor market experience, marital status, weeks worked, black and South variables are consistent with prior research, and in the interests of brevity comment is not provided. The estimates for the survey year variables indicate that, compared to the benchmark, real earnings in 2005, real earnings were one per cent lower in 2006, slightly higher in 2007, and over four per cent lower in the higher unemployment years, 2008 and 2009. ${ }^{9}$ The declines in real earnings in 2006, 2008 and 2009 were not neutral with respect to low-wage and high-wage workers, however. This matter is explored further when the quantile regression estimates are considered.

According to these estimates, bilinguals earn 4.7 per cent less than their English monolingual counterparts. This is consistent with analysis of the 1990 Census data by Chiswick and Miller (1998) that used a similar model of the earnings determination process. Workers who speak a language other than English at home and have limited English skills earn about seven percent less than the monolingual English-speaking group. The similarity of the findings for the two English proficiency variables in the Table 3 column (i) model suggests among men born in the U.S. that it is the use of a language other than English at home that is associated with lower earnings in the labor market, rather than their proficiency in English.

${ }^{9}$ The annual unemployment rate in the United States from 2005 to 2009 was

$\begin{array}{ll}\underline{\text { Year }} & \underline{\text { Percent }} \\ 2005 & 5.1 \\ 2006 & 4.6 \\ 2007 & 4.6 \\ 2008 & 5.8 \\ 2009 & 9.3\end{array}$

See also Chiswick and Miller (2002). 
Table 3

OLS Estimates of Earnings Equations with Language Skills Variables, Adult Native-born Men, US

\begin{tabular}{|c|c|c|}
\hline Variable & (i) & (ii) \\
\hline Constant & $\begin{array}{c}3.894 \\
(417.17)\end{array}$ & $\begin{array}{c}3.8989 \\
(417.50)\end{array}$ \\
\hline Educational attainment & $\begin{array}{c}0.120 \\
(434.24)\end{array}$ & $\begin{array}{c}0.120 \\
(432.79)\end{array}$ \\
\hline Experience (EXP) & $\begin{array}{c}0.044 \\
(174.64)\end{array}$ & $\begin{array}{c}0.044 \\
(174.80)\end{array}$ \\
\hline EXP squared/100 & $\begin{array}{c}-0.074 \\
(147.74)\end{array}$ & $\begin{array}{c}-0.074 \\
(147.95)\end{array}$ \\
\hline Married/Co-habitation & $\begin{array}{c}0.255 \\
(197.87)\end{array}$ & $\begin{array}{c}0.255 \\
(197.88)\end{array}$ \\
\hline Log weeks worked & $\begin{array}{c}1.154 \\
(533.45)\end{array}$ & $\begin{array}{c}1.154 \\
(533.30)\end{array}$ \\
\hline Black & $\begin{array}{l}-0.208 \\
(99.99)\end{array}$ & $\begin{array}{c}-0.208 \\
(100.26)\end{array}$ \\
\hline Year 2006 & $\begin{array}{l}-0.010 \\
(5.37)\end{array}$ & $\begin{array}{l}-0.010 \\
(5.38)\end{array}$ \\
\hline Year 2007 & $\begin{array}{l}0.006 \\
(3.14)\end{array}$ & $\begin{array}{l}0.006 \\
(3.15)\end{array}$ \\
\hline Year 2008 & $\begin{array}{l}-0.046 \\
(25.89)\end{array}$ & $\begin{array}{l}-0.046 \\
(25.87)\end{array}$ \\
\hline Year 2009 & $\begin{array}{l}-0.047 \\
(25.85)\end{array}$ & $\begin{array}{l}-0.047 \\
(25.80)\end{array}$ \\
\hline South & $\begin{array}{l}-0.044 \\
(37.58)\end{array}$ & $\begin{array}{l}-0.043 \\
(37.13)\end{array}$ \\
\hline $\begin{array}{l}\text { English very well (i.e., } \\
\text { bilingual) }\end{array}$ & $\begin{array}{c}-0.047 \\
(18.21)\end{array}$ & (a) \\
\hline $\begin{array}{l}\text { English well, not well or } \\
\text { not at all }\end{array}$ & $\begin{array}{c}-0.070 \\
(11.57)\end{array}$ & $\begin{array}{c}-0.070 \\
(11.65)\end{array}$ \\
\hline Spanish & (a) & $\begin{array}{l}-0.070 \\
(22.91)\end{array}$ \\
\hline Indigenous languages & (a) & $\begin{array}{l}-0.249 \\
(11.10)\end{array}$ \\
\hline $\begin{array}{l}\text { Other major second } \\
\text { languages }\end{array}$ & (a) & $\begin{array}{l}0.030 \\
(5.50)\end{array}$ \\
\hline $\begin{array}{l}\text { Residual second } \\
\text { languages }\end{array}$ & & $\begin{array}{l}-0.025 \\
(2.31)\end{array}$ \\
\hline R-Squared & 0.421 & 0.421 \\
\hline Sample size & $2,749,609$ & $2,749,609$ \\
\hline
\end{tabular}

Source: American Community Survey 2005-2009.

Notes: Robust ' $t$ ' statistics in parentheses. (a) = variable not entered. 
In the Table 3 column (ii) model the English proficiency bilingualism variable is replaced by four variables that reflect the non-English language spoken at home. The results show that English-Spanish bilinguals have earnings seven per cent lower than monolingual English speakers, English-Indigenous language bilinguals have earnings around 25 per cent lower than English monolinguals, and the English-other major second language bilinguals have an earnings advantage of about three per cent over the English monolingual benchmark group. The last bilingual variable shows that bilingual speakers of these less common foreign languages are associated with only slightly lower earnings in the US labor market, ceteris paribus (only 2.5 per cent).

As the unadjusted difference between the earnings of English monolinguals and English-Spanish bilinguals in Tables 1 and 2 was about 20 per cent, these regressions imply that two-thirds of this unadjusted difference is due to differences in the observed characteristics of the two language groups. In the comparison of English monolinguals and English-Indigenous language bilinguals, about one-half of the approximately 50 per cent unadjusted difference in earnings is due to differences in their observed characteristics. In the case of the bilinguals with other major second languages, their unadjusted earnings advantage was 12.7 per cent; hence it is apparent that much of this favorable earnings position is linked to differences in observed characteristics. Finally, the last group with the less common second languages are characterized by a 2.1 per cent unadjusted earnings differential, which is similar to the adjusted earnings differential of 2.5 per cent in the regression model.

Table 4 contains selected estimates obtained when more detailed information on the second language spoken by bilinguals is included in the estimating equation. Hence dummy variables for the 22 most commonly used second languages (see Table 2) are entered in the model. The results reveal considerable heterogeneity in the 
earnings outcomes for native-born bilinguals in the contemporary US labor market. With the other variables being equal, earnings effects are recorded for the bilinguals ranging from +22 per cent for Dutch to over minus 25 per cent for Yiddish and North American Indian languages. The estimates also reveal some important differences in the relative standing of particular groups of bilinguals compared to Table 2 .

Table 4 is structured by broad origin of the language, and the estimated effects for each broad group are ordered from highest to lowest. Hence, among the European languages, bilingual workers whose second language is either Dutch, Italian, Greek or Portuguese have a statistically significant earnings advantage over monolingual English speakers. At the other extreme, those who speak Spanish have a 7.0 per cent earnings disadvantage compared with English monolinguals. In between these extremes, there are workers who speak either Polish, German or French, whose earnings are not significantly different from the earnings of English monolinguals.

Two of the bilingual Indigenous language groups are associated with a statistically significant earnings disadvantage; -23 per cent for Navaho and -36 per cent for other North American Indian languages. These are predominantly economically isolated groups.

Turning to the Asian languages, the earnings effects range from +10.4 per cent (Cantonese) to -5.6 per cent (Tagalog). English-Korean bilinguals and EnglishChinese bilinguals are also associated with earnings advantages over English monolinguals, of 6.9 per cent and 5.0 per cent, respectively, while the earnings of English-Japanese and English-Vietnamese bilinguals do not differ statistically from the earnings of English monolinguals. 
Table 4

OLS Earnings Partial Effects for Major Language Groups, Adult Nativeborn Men, US

\begin{tabular}{|c|c|c|c|}
\hline \multicolumn{2}{|l|}{ Variable } & \multicolumn{2}{|l|}{ Variable } \\
\hline European Languages & & Asian Languages & \\
\hline Dutch & $\begin{array}{l}0.221 \\
(5.17)\end{array}$ & Cantonese & $\begin{array}{l}0.104 \\
(2.76)\end{array}$ \\
\hline Italian & $\begin{array}{l}0.096 \\
(6.80)\end{array}$ & Korean & $\begin{array}{l}0.069 \\
(2.41)\end{array}$ \\
\hline Greek & $\begin{array}{l}0.073 \\
(3.13)\end{array}$ & Chinese & $\begin{array}{l}0.050 \\
(1.96)\end{array}$ \\
\hline Russian & $\begin{array}{l}0.028 \\
(0.93)\end{array}$ & Japanese & $\begin{array}{l}-0.031 \\
(1.40)\end{array}$ \\
\hline Portuguese & $\begin{array}{l}0.063 \\
(2.89)\end{array}$ & Vietnamese & $\begin{array}{l}-0.052 \\
(1.33)\end{array}$ \\
\hline French & $\begin{array}{l}-0.000 \\
(0.04)\end{array}$ & Tagalog & $\begin{array}{l}-0.056 \\
(1.93)\end{array}$ \\
\hline German & $\begin{array}{l}-0.005 \\
(0.46)\end{array}$ & Other Languages & \\
\hline Polish & $\begin{array}{l}-0.023 \\
(0.76)\end{array}$ & Hebrew & $\begin{array}{l}0.099 \\
(2.58)\end{array}$ \\
\hline Spanish & $\begin{array}{l}-0.070 \\
(22.89)\end{array}$ & Arabic & $\begin{array}{l}-0.015 \\
(0.36)\end{array}$ \\
\hline Yiddish & $\begin{array}{l}-0.257 \\
(4.79)\end{array}$ & $\begin{array}{l}\text { Residual Second } \\
\text { Languages }\end{array}$ & $\begin{array}{l}-0.025 \\
(2.32)\end{array}$ \\
\hline Indigenous Language & & & \\
\hline Navaho & $\begin{array}{l}-0.226 \\
(7.58)\end{array}$ & & \\
\hline $\begin{array}{l}\text { North-American } \\
\text { Indian Languages }\end{array}$ & $\begin{array}{l}-0.359 \\
(9.07)\end{array}$ & & \\
\hline $\begin{array}{l}\text { Pennsylvania } \\
\text { Dutch }\end{array}$ & $\begin{array}{c}0.367 \\
(10.34)\end{array}$ & & \\
\hline
\end{tabular}

Source: American Community Survey 2005-2009.

Notes: Robust 't' statistics in parentheses. The language benchmark is monolingual English speakers.

Finally, among the other languages, there are two languages associated with significant earnings premiums, the Pennsylvania Dutch (36.7 per cent) and Hebrew (9.9 per cent), and one (Yiddish) with a large earnings disadvantage relative to the English monolingual benchmark group. The Pennsylvania Dutch earnings effect (a large premium) is quite different from that seen in the unadjusted averages of Table 2 
(an earnings disadvantage), and the earnings premium for Hebrew is much smaller than that evident in the unadjusted averages of Table 2.

Hence, the differences by language group show that bilinguals should not be treated as a single group. There are obviously either unobserved differences across the workers that are correlated with the particular second language spoken, or demandside factors are at play, that lead to quite different labor market outcomes.

As noted with respect to the Table 3 results, adjusting for observed characteristics is clearly important when assessing the labor market position of nativeborn bilingual workers in the US labor market. But what roles do unobserved factors play?

\section{(c) Quantile Regression}

Quantile regression offers a means of gathering further information on the effects on earnings of language and other human capital skills. It provides a characterization of the links between explanatory variables (educational attainment, experience, language skills, etc.) and the position of the various quantiles of the earnings distribution. In this paper we focus on deciles. Moreover, it is generally argued that workers at a given decile in the earnings distribution will be more homogenous in terms of unobserved characteristics than workers across the earnings distribution. Hence, examination of the effects on earnings of particular explanatory variables at a specific decile is an indirect way of controlling for the unobserved characteristics, for example ability, that are argued to bias OLS estimates. Comparison of the estimates for a particular explanatory variable from lower to higher deciles gives information on the complementarity or substitutability of the 
explanatory variable of interest and those unobserved characteristics that also affect earnings (Patrinos, Ridao-Cano and Sakellariou, 2006).

Appendix Table B-1 presents quantile regression estimates of the extended specification of the earnings equation of Table 3 column (ii), and Appendix Table B-2 presents selected quantile regression estimates from the model that contains the more detailed language information.

Prior to discussing the estimates associated with the language variables it is useful to comment on several of the other variables. First, the coefficient on educational attainment increases monotonically across the earnings distribution, from 0.104 at the first decile to 0.145 at the ninth decile. This pattern is typical in the literature (Martins and Pereira, 2004), and is also a feature of previous quantile regression estimates for the native born in the US (Chiswick, Le and Miller, 2008). That is, the effect of schooling on earnings increases with the level of schooling. In comparison, the estimates for the labor market experience variables are fairly constant across the earnings distribution, whereas the earnings premium for being married and weeks worked decline at higher deciles. Indeed, at the seventh and higher deciles, estimates for the weeks worked variable are consistent with a backward-bending labor supply curve.

Finally, it is noted that the year dichotomous variables, for 2006, 2008 and 2009, that were associated with a negative effect on earnings compared to 2005 in the OLS estimates of Table 3, are shown here to have negative effects across the distribution of earnings. In the case of the more pronounced negative effects for 2008 and 2009, the earnings decline was greatest for low-wage workers. In other words, lower earnings for 2008 and 2009 during the Great Recession were experienced more intensely among the lowest paid/least skilled workers. 
Turning to the language variables, it is noted that the coefficient of the variable for limited English skills is negative, sizeable, and highly statistically significant at the first decile, and this disadvantage dissipates as higher deciles are considered. The earnings differential for this group compared to English monolinguals is positive and statistically significant at the ninth decile. An explanation for this pattern is that the unobserved characteristics of workers that lead to favorable earnings are higher at higher deciles of the distribution of earnings, and these help mask the negative effects on earnings of any English language deficiencies.

A similar pattern is evident with regards to bilingualism. English-Spanish bilingualism is associated with lower earnings across the distribution of earnings. The negative effect, however, is more intense in the bottom half of the distribution than it is across the upper deciles. Hence, across the bottom half of the distribution of earnings, English-Spanish bilinguals earn between 6.0 and 8.1 per cent less than the English monolingual benchmark group. Across the sixth to the ninth deciles, the earnings disadvantage of this group of bilinguals is from 5.5 per cent to 2.6 per cent. Note, moreover, the generally monotonic pattern in the decline in the earnings disadvantage of English-Spanish bilinguals as higher deciles are considered.

The English-Indigenous language bilinguals are characterized by a pronounced earnings disadvantage at all parts of the distribution of earnings. This ranges from 22.7 per cent (decile three) to 28.6 per cent (decile nine). Unlike the other groups of bilinguals considered, the changes in this disadvantage from decile to decile are not monotonic.

English-other (major) language bilinguals are characterized by lower earnings than English monolinguals at the bottom decile, but they have significantly higher earnings than English monolinguals at the third decile and higher deciles. Again, the 
earnings differential between this group of bilinguals and English monolinguals has a uniform pattern as higher deciles are considered. Finally, in the case of the residual group of the least spoken languages, the earnings effects are negative and statistically significant across the bottom five deciles, and statistically insignificant across the top four deciles.

Hence, controlling for unobservables by considering the earnings differences associated with bilingualism at particular deciles of the distribution of earnings reveals that the other major language bilinguals have higher earnings than their English monolingual counterparts.

Appendix Table B-2 presents the estimates from the specification that is based on the more detailed second language information. There are three main features of the result in this table. First, in general, other variables the same, at each decile the hierarchy in terms of earnings of the various second language groups is generally maintained: Pennsylvania Dutch, Dutch, Cantonese, Chinese, Korean and Hebrew have relatively high earnings positions, Italian and Portuguese have moderately high earnings positions, and Spanish, Tagalog, the Indigenous language groups, and Yiddish have relatively low earnings positions. Second, with the exception of Chinese and Cantonese, there is a tendency for the estimated coefficients for the language groups with the more favorable earnings outcomes to increase in size as higher deciles are considered. Third, in the case of bilinguals with Chinese or Cantonese as their second language, who were shown in the OLS estimates (Table 4) to be associated with conditional mean earnings above those of English monolinguals, the quantile regression estimates reveal earnings premiums (of up to 20 per cent) across the bottom portion of the distribution, which decrease in size as higher deciles are examined. The earnings of these two groups of bilinguals are not significantly 
different from the earnings of the English monolingual benchmark group at the eighth and ninth deciles, however. The bilingual language skills of these workers do not, therefore, appear to be rewarded in high-wage jobs.

\section{$\underline{\text { IV. Summary and Conclusions }}$}

This paper studies the effect of bilingualism on the earnings of adult (age 25 to 64) men born in the United States, using the 2005-2009 pooled PUMS files of the American Community Survey (ACS). Bilinguals are defined in this study as those speak a language at home other than or in addition to English.

Bilingualism is rare. Among adult men 93.5 percent report speaking only English at home, while 6.5 report a non-English language. Of the latter, 71 percent report Spanish, with 29 percent indicating another language. German (5 percent), French (4 percent) and Italian (3 percent) are the most frequent of those, with all other languages at less than two percent. Of those who spoke another language most reported speaking English “very well” (85 percent), with others responding “well” (10 percent), "not well” (4.6 percent) or not at all, only a few words (0.6 percent).

Bilinguals may have an earnings advantage because of a labor market demand for workers who can communicate with others in a language other than English. Knowing another language may also reflect on or enhance other dimensions of ability relevant for the labor market. Yet, knowing another language may detract from earnings, if it is associated with a poorer proficiency in English, perhaps because there is less investment in English or it is associated with close ties to an immigrant, ethnic, religious or linguistic communication enclave. Moreover, there may be discrimination against second language speakers. 
Overall, among adult native-born men monolingual English speakers earned $\$ 56,515$ in 2005 dollars, while those who reported another language but spoke English very well earned 12 percent less, \$49,588. Earnings were lower for those with a lower level of English proficiency.

Other variables held constant, those who speak another language earn a statistically significant 4.7 percent less than monolingual English speakers. But this statistic masks substantial variability in earnings differentials across linguistic groups. Those who speak indigenous native American languages (Navaho, Eskimo or other North American Indian languages), Pennsylvania Dutch, Yiddish, or Vietnamese earn much less than monolingual English speakers. Living and working within enclaves, whether they are geographic enclaves, (e.g. isolated rural areas or native peoples reservations) or self-imposed cultural or religious enclaves (e.g. Pennsylvania Dutch and Yiddish speakers) may limit their opportunities for formal secular schooling, onthe-job-training, and employment in the general U.S. labor market.

Other groups, however, earn more than the monolingual English speakers. Those who speak certain West European languages (i.e., Dutch, Italian, Greek , and Portuguese), certain East Asian languages (i.e., Cantonese, Chinese, Korean) and Hebrew earn, on average, significantly more than statistically similar monolingual English speakers. This may reflect the large proportion of second generation Americans in these groups, and the sons of immigrants tend to earn more than the sons of native-born parents (Chiswick 1977). Some of these languages may provide economic advantages in international trade or finance.

Spanish speakers are by far the largest linguistic group after English, and their earnings are significantly lower than monolingual English speakers. The observed earnings differential is 20 percent. Even after controlling for their lower level of 
schooling, and other variables, they earn a statistically significant 7 percent less than monolingual English speakers. That is, two-thirds of their lower earnings are explained by observed characteristics, but one-third remains.

There is a tendency for the ranking of language groups by their earnings to be similar if the ranking is by observed earnings or by earnings when other variables, particularly schooling, are held constant; controlling for other explanatory variables does tend to narrow group differences in earnings. A notable exception are the Pennsylvania Dutch speakers who have very low levels of formal schooling and very low observed earnings, but when explanatory variables are held constant, they show significantly higher earnings than monolingual English speakers.

Thus, the short answer to the question in the title "Does Bilingualism Among the Native Born Pay?” is that it depends on the language spoken and on the reasons for the bilingualism. 


\section{Appendix A: Definitions of the Variables}

Data Source: American Community Survey, 2005-2009, PUMS

Definition of Population: Adult men (ages 25-64) born in the United States who had non-zero earnings and worked in the prior year.

Dependent Variable: Natural logarithm of earnings in the prior year expressed in 2005 dollars, where earnings are the sum of wage, salary and self-employment income. Observation deleted if there were zero earnings.

\section{Explanatory Variables}

Educational Attainment: Years of full time equivalent schooling attained.

Experience: Age minus schooling minus 6.

Married/Co-habitation: Dichotomous variable equal to unity if currently married or cohabitating, otherwise equals zero.

Log Weeks Worked: Natural logarithm of weeks worked in the prior year. Observation deleted if there were zero weeks worked.

Black: Dichotomous variable equal to unity for men reporting their race as Black or African-American, otherwise equals zero.

South: Dichotomous variable equal to unity for persons living in one of the 17 southern states and the District of Columbia, otherwise equals zero.

Year: Dichotomous variable equal to unity for the survey year, equal to zero otherwise. Year 2005 is the benchmark.

English Proficiency: Dichotomous variables for speaking at home: Speaks English very well, well, not well, or not at all equals unity, otherwise equals zero. The benchmark is speaks only English at home (monolingual English speakers).

Indigenous Languages: Dichotomous variable equal to unity for Navaho, other North American Indian languages, and Eskimo, otherwise equals zero.

Spanish, Other Major Second Languages, and Residual Second Languages: Dichotomous variables equal to unity if the person speaks at home Spanish, any of the 21 other most frequently spoken languages by the native-born (listed in Table 2), and all other second languages, otherwise equals zero. 
Languages: Dichotomous variables for individual languages coded as unity, otherwise equals zero. 


\section{Appendix B: Quantile Regressions}

Appendix Table B-1

Selected Estimates for Major Language Groups from Quantile Regressions of Earnings Equations for Native-born Men, US

\begin{tabular}{|lccccccccc|}
\hline & & & & \multicolumn{3}{c}{ Decile } & & & \\
Variables & $\mathbf{0 . 1}$ & $\mathbf{0 . 2}$ & $\mathbf{0 . 3}$ & $\mathbf{0 . 4}$ & $\mathbf{0 . 5}$ & $\mathbf{0 . 6}$ & $\mathbf{0 . 7}$ & $\mathbf{0 . 8}$ \\
\hline Constant & 1.798 & 2.138 & 2.493 & 2.980 & 3.532 & 4.081 & 4.665 & 5.419 & 6.362 \\
& $(71.66)$ & $(134.86)$ & $(182.97)$ & $(238.60)$ & $(287.21)$ & $(338.50)$ & $(374.78)$ & $(378.38)$ & $(317.92)$ \\
Educational & 0.104 & 0.108 & 0.114 & 0.119 & 0.122 & 0.126 & 0.130 & 0.134 & 0.145 \\
attainment & $(116.36)$ & $(192.72)$ & $(235.31)$ & $(268.14)$ & $(279.88)$ & $(293.99)$ & $(293.20)$ & $(263.08)$ & $(203.57)$ \\
Experience & 0.051 & 0.045 & 0.043 & 0.043 & 0.044 & 0.043 & 0.044 & 0.045 & 0.046 \\
EXP) & $(56.94)$ & $(79.50)$ & $(88.68)$ & $(96.07)$ & $(98.39)$ & $(98.66)$ & $(97.42)$ & $(86.96)$ & $(64.08)$ \\
EXP squared/100 & -0.108 & -0.087 & -0.078 & -0.074 & -0.072 & -0.069 & -0.068 & -0.068 & -0.066 \\
& $(61.83)$ & $(78.92)$ & $(82.21)$ & $(84.87)$ & $(84.07)$ & $(81.69)$ & $(78.58)$ & $(68.23)$ & $(47.27)$ \\
Married/Co- & 0.360 & 0.287 & 0.251 & 0.231 & 0.217 & 0.207 & 0.196 & 0.190 & 0.197 \\
habitation & $(75.64)$ & $(95.57)$ & $(97.09)$ & $(97.67)$ & $(92.97)$ & $(90.62)$ & $(82.83)$ & $(69.80)$ & $(51.98)$ \\
Log weeks & 1.537 & 1.533 & 1.476 & 1.371 & 1.249 & 1.129 & 0.997 & 0.826 & 0.600 \\
worked & $(293.38)$ & $(463.07)$ & $(518.75)$ & $(525.72)$ & $(486.26)$ & $(448.44)$ & $(383.71)$ & $(276.16)$ & $(143.62)$ \\
Black & -0.192 & -0.189 & -0.192 & -0.200 & -0.197 & -0.202 & -0.204 & -0.208 & -0.225 \\
& $(24.15)$ & $(37.71)$ & $(44.52)$ & $(50.66)$ & $(50.62)$ & $(52.90)$ & $(51.74)$ & $(45.90)$ & $(35.59)$ \\
Year 2006 & -0.003 & -0.006 & -0.013 & -0.010 & -0.007 & -0.011 & -0.007 & -0.007 & -0.005 \\
& $(0.39)$ & $(1.38)$ & $(3.58)$ & $(3.04)$ & $(2.28)$ & $(3.39)$ & $(2.09)$ & $(1.95)$ & $(0.92)$ \\
Year 2007 & 0.009 & 0.002 & -0.004 & -0.003 & 0.004 & 0.001 & 0.010 & 0.011 & 0.013 \\
& $(1.39)$ & $(0.43)$ & $(1.09)$ & $(0.96)$ & $(1.31)$ & $(0.24)$ & $(3.06)$ & $(2.90)$ & $(2.43)$ \\
Year 2008 & -0.063 & -0.051 & -0.049 & -0.045 & -0.035 & -0.036 & -0.027 & -0.021 & -0.018 \\
& $(9.47)$ & $(12.03)$ & $(13.53)$ & $(13.49)$ & $(10.58)$ & $(11.18)$ & $(8.14)$ & $(5.57)$ & $(3.47)$ \\
\hline
\end{tabular}


Table B-1 Continued

\begin{tabular}{|c|c|c|c|c|c|c|c|c|c|}
\hline \multicolumn{10}{|c|}{ Table B-1 Continued } \\
\hline Year 2009 & $\begin{array}{l}-0.057 \\
(8.53)\end{array}$ & $\begin{array}{l}-0.040 \\
(9.52)\end{array}$ & $\begin{array}{l}-0.035 \\
(9.57)\end{array}$ & $\begin{array}{l}-0.033 \\
(9.99)\end{array}$ & $\begin{array}{l}-0.026 \\
(7.79)\end{array}$ & $\begin{array}{l}-0.026 \\
(8.08)\end{array}$ & $\begin{array}{l}-0.018 \\
(5.29)\end{array}$ & $\begin{array}{l}-0.019 \\
(4.86)\end{array}$ & $\begin{array}{l}-0.026 \\
(4.85)\end{array}$ \\
\hline South & $\begin{array}{l}-0.030 \\
(6.83)\end{array}$ & $\begin{array}{l}-0.048 \\
(17.28)\end{array}$ & $\begin{array}{l}-0.051 \\
(21.23)\end{array}$ & $\begin{array}{l}-0.046 \\
(20.79)\end{array}$ & $\begin{array}{l}-0.043 \\
(20.06)\end{array}$ & $\begin{array}{l}-0.032 \\
(15.28)\end{array}$ & $\begin{array}{l}-0.025 \\
(11.46)\end{array}$ & $\begin{array}{l}-0.020 \\
(8.14)\end{array}$ & $\begin{array}{l}-0.018 \\
(5.04)\end{array}$ \\
\hline $\begin{array}{l}\text { English well, not } \\
\text { well or not at all }\end{array}$ & $\begin{array}{l}-0.158 \\
(7.36)\end{array}$ & $\begin{array}{l}-0.126 \\
(9.29)\end{array}$ & $\begin{array}{l}-0.097 \\
(8.33)\end{array}$ & $\begin{array}{l}-0.082 \\
(7.67)\end{array}$ & $\begin{array}{l}-0.062 \\
(5.89)\end{array}$ & $\begin{array}{l}-0.043 \\
(4.14)\end{array}$ & $\begin{array}{l}-0.024 \\
(2.23)\end{array}$ & $\begin{array}{l}-0.002 \\
(0.15)\end{array}$ & $\begin{array}{l}0.053 \\
(3.08)\end{array}$ \\
\hline Spanish & $\begin{array}{l}-0.081 \\
(6.79)\end{array}$ & $\begin{array}{l}-0.080 \\
(10.57)\end{array}$ & $\begin{array}{c}-0.072 \\
(11.12)\end{array}$ & $\begin{array}{c}-0.065 \\
(10.92)\end{array}$ & $\begin{array}{c}-0.060 \\
(10.28)\end{array}$ & $\begin{array}{l}-0.055 \\
(9.54)\end{array}$ & $\begin{array}{l}-0.045 \\
(7.59)\end{array}$ & $\begin{array}{l}-0.029 \\
(4.20)\end{array}$ & $\begin{array}{l}-0.026 \\
(2.76)\end{array}$ \\
\hline $\begin{array}{l}\text { Indigenous } \\
\text { languages }\end{array}$ & $\begin{array}{l}-0.241 \\
(3.54)\end{array}$ & $\begin{array}{l}-0.226 \\
(5.25)\end{array}$ & $\begin{array}{l}-0.227 \\
(6.12)\end{array}$ & $\begin{array}{l}-0.257 \\
(7.56)\end{array}$ & $\begin{array}{l}-0.270 \\
(8.06)\end{array}$ & $\begin{array}{l}-0.243 \\
(7.41)\end{array}$ & $\begin{array}{l}-0.264 \\
(7.79)\end{array}$ & $\begin{array}{l}-0.229 \\
(5.87)\end{array}$ & $\begin{array}{l}-0.286 \\
(5.26)\end{array}$ \\
\hline $\begin{array}{l}\text { Other major } \\
\text { second languages }\end{array}$ & $\begin{array}{l}-0.041 \\
(2.11)\end{array}$ & $\begin{array}{l}0.015 \\
(1.19)\end{array}$ & $\begin{array}{l}0.030 \\
(2.89)\end{array}$ & $\begin{array}{l}0.042 \\
(4.39)\end{array}$ & $\begin{array}{l}0.050 \\
(5.23)\end{array}$ & $\begin{array}{l}0.061 \\
(6.50)\end{array}$ & $\begin{array}{l}0.069 \\
(7.14)\end{array}$ & $\begin{array}{l}0.081 \\
(7.30)\end{array}$ & $\begin{array}{l}0.107 \\
(6.93)\end{array}$ \\
\hline $\begin{array}{l}\text { Residual second } \\
\text { languages }\end{array}$ & $\begin{array}{l}-0.104 \\
(2.58)\end{array}$ & $\begin{array}{l}-0.064 \\
(2.49)\end{array}$ & $\begin{array}{l}-0.052 \\
(2.39)\end{array}$ & $\begin{array}{l}-0.054 \\
(2.66)\end{array}$ & $\begin{array}{l}-0.033 \\
(1.66)\end{array}$ & $\begin{array}{l}-0.014 \\
(0.73)\end{array}$ & $\begin{array}{l}0.001 \\
(0.03)\end{array}$ & $\begin{array}{l}0.034 \\
(1.49)\end{array}$ & $\begin{array}{l}0.047 \\
(1.45)\end{array}$ \\
\hline Pseudo $\mathrm{R}^{2}$ & 0.322 & 0.291 & 0.261 & 0.238 & 0.220 & 0.206 & 0.195 & 0.183 & 0.171 \\
\hline Sample size & 549,919 & 549,919 & 549,919 & 549,919 & 549,919 & 549,919 & 549,919 & 549,919 & 549,919 \\
\hline
\end{tabular}

Source: American Community Survey 2005-2009.

Notes: Robust ' $\mathrm{t}$ ' statistics in parentheses. (a) = variable not entered. 
Appendix Table B-2

Quantile Regressions of Earnings Equations for Native-born Men, US

\begin{tabular}{|c|c|c|c|c|c|c|c|c|c|}
\hline \multirow[b]{2}{*}{ Variables } & \multicolumn{9}{|c|}{ Decile } \\
\hline & 0.1 & 0.2 & 0.3 & 0.4 & 0.5 & 0.6 & 0.7 & 0.8 & 0.9 \\
\hline $\begin{array}{l}\text { Educational } \\
\text { attainment }\end{array}$ & $\begin{array}{c}0.104 \\
(116.14)\end{array}$ & $\begin{array}{c}0.108 \\
(193.17)\end{array}$ & $\begin{array}{c}0.114 \\
(236.26)\end{array}$ & $\begin{array}{c}0.119 \\
(267.91)\end{array}$ & $\begin{array}{c}0.122 \\
(279.18)\end{array}$ & $\begin{array}{c}0.126 \\
(293.52)\end{array}$ & $\begin{array}{c}0.130 \\
(294.22)\end{array}$ & $\begin{array}{c}0.134 \\
(263.35)\end{array}$ & $\begin{array}{c}0.145 \\
(204.32)\end{array}$ \\
\hline \multicolumn{10}{|l|}{ European Languages } \\
\hline \multirow[t]{2}{*}{ Dutch } & -0.144 & 0.125 & 0.202 & 0.224 & 0.237 & 0.325 & 0.295 & 0.422 & 0.734 \\
\hline & $(0.97)$ & $(1.32)$ & $(2.50)$ & $(3.02)$ & (3.23) & $(4.52)$ & $(4.00)$ & $(4.96)$ & (6.18) \\
\hline \multirow[t]{2}{*}{ Italian } & 0.123 & 0.100 & 0.117 & 0.128 & 0.112 & 0.116 & 0.122 & 0.116 & 0.150 \\
\hline & $(2.26)$ & $(2.92)$ & $(4.00)$ & $(4.74)$ & (4.21) & $(4.44)$ & (4.55) & (3.76) & (3.49) \\
\hline \multirow[t]{2}{*}{ Portuguese } & 0.063 & 0.099 & 0.132 & 0.082 & 0.104 & 0.093 & 0.119 & 0.169 & 0.251 \\
\hline & $(0.76)$ & (1.89) & (2.93) & (1.98) & (2.54) & (2.31) & (2.89) & (3.55) & (3.80) \\
\hline \multirow[t]{2}{*}{ Greek } & -0.072 & 0.048 & 0.055 & 0.016 & 0.007 & 0.030 & 0.017 & 0.071 & 0.122 \\
\hline & $(0.84)$ & (0.89) & (1.19) & (0.38) & $(0.16)$ & $(0.74)$ & $(0.40)$ & (1.46) & (1.80) \\
\hline \multirow[t]{2}{*}{ Polish } & 0.076 & 0.080 & 0.031 & 0.051 & 0.030 & 0.031 & 0.034 & -0.017 & -0.132 \\
\hline & $(0.70)$ & (1.16) & $(0.52)$ & $(0.94)$ & $(0.57)$ & $(0.60)$ & $(0.63)$ & $(0.28)$ & (1.52) \\
\hline \multirow[t]{2}{*}{ French } & -0.099 & -0.017 & 0.005 & 0.008 & 0.022 & 0.025 & 0.038 & 0.062 & 0.135 \\
\hline & $(2.25)$ & $(0.60)$ & (0.19) & $(0.35)$ & (1.00) & (1.18) & (1.75) & (2.49) & (3.86) \\
\hline \multirow[t]{2}{*}{ German } & -0.083 & -0.012 & -0.020 & -0.003 & 0.020 & 0.044 & 0.046 & 0.064 & 0.044 \\
\hline & $(2.05)$ & $(0.46)$ & $(0.92)$ & $(0.15)$ & (1.03) & (2.25) & (2.30) & (2.78) & (1.36) \\
\hline \multirow[t]{2}{*}{ Spanish } & -0.080 & -0.080 & -0.073 & -0.065 & -0.060 & -0.055 & -0.045 & -0.029 & -0.026 \\
\hline & (6.73) & (10.62) & (11.22) & (10.93) & (10.23) & (9.54) & (7.67) & $(4.20)$ & $(2.72)$ \\
\hline \multicolumn{10}{|l|}{ Indigenous Languages } \\
\hline \multirow{2}{*}{ Eskimo Languages } & -0.627 & -0.373 & -0.302 & -0.215 & -0.090 & -0.016 & 0.067 & -0.055 & -0.089 \\
\hline & $(3.50)$ & (3.31) & (3.12) & $(2.42)$ & (1.03) & $(0.19)$ & $(0.76)$ & $(0.54)$ & $(0.63)$ \\
\hline \multirow[t]{2}{*}{ Navaho } & -0.144 & -0.109 & -0.166 & -0.191 & -0.163 & -0.193 & -0.199 & -0.200 & -0.243 \\
\hline & $(1.55)$ & (1.86) & (3.31) & $(4.13)$ & (3.56) & $(4.31)$ & (4.33) & $(3.77)$ & (3.29) \\
\hline North-American & -0.335 & -0.328 & -0.324 & -0.403 & -0.430 & -0.455 & -0.493 & -0.434 & -0.393 \\
\hline Indian Languages & $(2.77)$ & $(4.30)$ & $(4.95)$ & (6.68) & $(7.22)$ & $(7.80)$ & $(8.23)$ & (6.29) & $(4.08)$ \\
\hline
\end{tabular}


Table B-2 Continued

Asian Languages

\begin{tabular}{|c|c|c|c|c|c|c|c|c|c|}
\hline Cantonese & $\begin{array}{c}-0.023 \\
(0.14)\end{array}$ & $\begin{array}{c}0.108 \\
(1.09)\end{array}$ & $\begin{array}{l}0.196 \\
(2.30)\end{array}$ & $\begin{array}{l}0.188 \\
(2.40)\end{array}$ & $\begin{array}{l}0.173 \\
(2.23)\end{array}$ & $\begin{array}{l}0.157 \\
(2.07)\end{array}$ & $\begin{array}{l}0.157 \\
(2.01)\end{array}$ & $\begin{array}{l}0.097 \\
(1.08)\end{array}$ & $\begin{array}{c}-0.083 \\
(0.66)\end{array}$ \\
\hline \multirow[t]{2}{*}{ Korean } & 0.158 & 0.090 & 0.043 & 0.084 & 0.081 & 0.057 & 0.027 & -0.006 & 0.054 \\
\hline & (1.34) & $(1.22)$ & $(0.67)$ & (1.44) & $(1.41)$ & $(1.00)$ & $(0.46)$ & $(0.08)$ & $(0.57)$ \\
\hline \multirow[t]{2}{*}{ Chinese } & 0.211 & 0.172 & 0.180 & 0.133 & 0.107 & 0.085 & 0.078 & 0.082 & 0.044 \\
\hline & $(2.22)$ & (2.88) & (3.51) & $(2.82)$ & (2.29) & $(1.85)$ & (1.67) & $(1.51)$ & $(0.58)$ \\
\hline \multirow[t]{2}{*}{ Japanese } & 0.001 & -0.043 & -0.018 & 0.022 & 0.018 & -0.008 & -0.028 & -0.012 & 0.102 \\
\hline & $(0.01)$ & $(0.78)$ & (0.39) & $(0.50)$ & $(0.42)$ & (0.19) & $(0.64)$ & $(0.24)$ & (1.48) \\
\hline \multirow[t]{2}{*}{ Vietnamese } & -0.044 & 0.019 & 0.001 & 0.010 & 0.066 & 0.083 & 0.075 & 0.127 & 0.072 \\
\hline & $(0.30)$ & $(0.20)$ & $(0.01)$ & $(0.13)$ & $(0.90)$ & (1.16) & $(1.01)$ & (1.49) & $(0.61)$ \\
\hline \multirow[t]{2}{*}{ Tagalog } & -0.094 & -0.114 & -0.087 & -0.078 & -0.116 & -0.093 & -0.143 & -0.090 & -0.159 \\
\hline & $(0.81)$ & (1.57) & $(1.40)$ & $(1.36)$ & $(2.05)$ & (1.68) & $(2.51)$ & (1.37) & (1.74) \\
\hline \multicolumn{10}{|l|}{ Other Languages } \\
\hline \multirow[t]{2}{*}{ Pennsylvania Dutch } & 0.174 & 0.143 & 0.118 & 0.189 & 0.232 & 0.259 & 0.274 & 0.304 & 0.571 \\
\hline & (1.60) & (2.09) & $(2.00)$ & (3.49) & $(4.34)$ & (4.95) & (5.09) & $(4.90)$ & (6.60) \\
\hline \multirow[t]{2}{*}{ Hebrew } & -0.087 & -0.050 & 0.188 & 0.139 & 0.161 & 0.158 & 0.159 & 0.221 & 0.285 \\
\hline & $(0.74)$ & $(0.68)$ & (2.97) & (2.37) & (2.79) & $(2.80)$ & $(2.74)$ & (3.30) & (3.06) \\
\hline \multirow[t]{2}{*}{ Russian } & -0.209 & -0.113 & -0.071 & 0.033 & -0.017 & -0.047 & -0.061 & -0.078 & -0.096 \\
\hline & (1.68) & (1.44) & (1.06) & (0.53) & $(0.27)$ & $(0.79)$ & (0.99) & (1.10) & $(0.97)$ \\
\hline \multirow[t]{2}{*}{ Arabic } & -0.009 & -0.044 & -0.012 & -0.037 & -0.016 & 0.007 & 0.059 & 0.066 & 0.264 \\
\hline & $(0.08)$ & $(0.57)$ & $(0.17)$ & $(0.61)$ & $(0.26)$ & $(0.12)$ & (0.97) & $(0.95)$ & $(2.71)$ \\
\hline Residual second & -0.104 & -0.064 & -0.052 & -0.052 & -0.033 & -0.014 & 0.001 & 0.035 & 0.047 \\
\hline languages & $(2.57)$ & $(2.50)$ & (2.39) & $(2.58)$ & (1.65) & $(0.74)$ & $(0.04)$ & (1.50) & (1.48) \\
\hline \multirow[t]{2}{*}{ Yiddish } & -0.785 & -0.703 & -0.497 & -0.303 & -0.284 & -0.181 & -0.058 & 0.115 & 0.054 \\
\hline & $(5.42)$ & $(7.70)$ & $(6.35)$ & $(4.20)$ & (3.99) & $(2.59)$ & $(0.82)$ & $(1.39)$ & $(0.47)$ \\
\hline Pseudo $\mathrm{R}^{2}$ & 0.322 & 0.291 & 0.261 & 0.238 & 0.220 & 0.206 & 0.195 & 0.183 & 0.171 \\
\hline Sample size & 549,919 & 549,919 & 549,919 & 549,919 & 549,919 & 549,919 & 549,919 & 549,919 & 549,919 \\
\hline
\end{tabular}

Source: American Community Survey 2005-2009. Notes: Robust 't' statistics in parentheses. (a) = variable not entered. 


\section{REFERENCES}

Becker, G. S., (1957). The Economics of Discrimination, The University of Chicago Press, Chicago.

Becker, G. S., (1964). Human Capital, National Bureau of Economic Research, New York.

Chiswick, B. R., (1977). "Sons of Immigrants: Are They at an Earnings Disadvantage?”, American Economic Review, Vol. 67, No. 1, pp. 376-380.

Chiswick, B. R., Le, A. T. and Miller, P. W., (2008). "How Immigrants Fare Across the Earnings Distribution: International Analyses", Industrial and Labor Relations Review, Vol. 61, No. 3, pp.353-373.

Chiswick, B. R. and Miller, P. W., (1995). “The Endogeneity Between Language and Earnings: International Analysis”, Journal of Labor Economics, Vol. 13, No. 2, pp. 246-288.

Chiswick, B. R. and Miller, P. W., (1998). "The Economic Cost to Native-Born Americans of Limited English Language Proficiency", Report Prepared for the Center for Equal Opportunity, available www.ceouwa.org/earnings.html. Reprinted in Chiswick and Miller 2007a, pp. 413-430.

Chiswick, B. R. and Miller, P. W., (2002). "Immigrant Earnings: Linguistic Concentrations and the Business Cycle”, Journal of Population Economics, Vol. 15, No.1, pp.31-57.

Chiswick, B. R. and Miller, P. W., (2005). "Do Enclaves Matter in Immigrant Adjustment?”, City and Community, Vol. 4, No. 1, pp. 5-35. Barry R.

Chiswick, B. R. and Paul W. Miller (2007a) The Economics of Language: International Analyses, Routledge, London.

Chiswick, B. R. and Miller, P. W., (2008). “Modelling Immigrants’ Language Skills”, Research in Labor Economics, Vol. 27, pp. 75-128.

Christofides, L. and Swidinsky, R., (2010). “The Economic Returns to the Knowledge and Use of a Second Official Language: English in Quebec and French in the Rest-Of-Canada”, Canadian Public Policy, Vol. 36, No. 2, pp. 137-158.

Coomer, N. M., (2011). "Returns to Bilingualism in the Nursing Labor Market Demand or Ability?”, The Journal of Socio-Economics, Vol. 40, No. 3, pp. 274-284.

Fry, R. and Lowell, B. L., (2003). "The Value of Bilingualism in the US Labor Market”, Industrial and Labor Relations Review, Vol. 57, No. 1, pp. 128-140.

Fry, R. and Lowell, B. L., (2005). "The Characteristics of Bilingual and Monolingual U.S. Workers”, in James Cohen, Kara McAlister, Kellie Rolstad and Jeff 
MacSwan (eds.) Proceedings of the $4^{\text {th }}$ International Symposium on Bilingualism, Cascadilla Press, Somerville, MA, pp. 787-799.

Ginsburgh, Victor, and Prieto-Rodriguez, J., (2003). "Returns to Foreign Languages of Native Workers in the European Union”, Industrial and Labor Relations Review, Vol. 64, No. 3, pp. 599-618.

Henley, A. and Jones, R. E., (2005). "Earnings and Linguistic Proficiency in a Bilingual Economy”, The Manchester School, Vol. 73, No. 3, pp. 300-320.

Linton, A., (2004). "A Critical Mass Model of Bilingualism Among US-Born Hispanics”, Social Forces, Vol. 83, No.1, pp. 279-314.

Phelps, E. S., (1972). “The Statistical Theory of Racism and Sexism”, American Economic Review, Vol. 62, No. 4, pp.659-661.

Shin, Hyoung-jin. and Alba, Richard, (2009). “The Economic Value of Bilingualism for Asians and Hispanics”, The Sociological Forum, Vol. 24, No. 2, pp. 254275.

Toomet, Ott (2011) "Learn English, Not the Local Language! Ethnic Russians in the Baltic States" American Economics Review, Papers and Proceedings. 101 (3), May, pp. 526-531 